\title{
The Protection of Flora and Vegetation of the Mountain Jahorina
}

\author{
Sladjana Petronic*, Natasa Bratic, Stefan Bojic \\ University of East Sarajevo, Faculty of Agriculture
}

* Corresponding author: sladjanapetronic2504@gmail.com

\begin{abstract}
This paper describes the protection of the flora and vegetation of the Mountain Jahorina. The total area of protected landscape Javorina is $11,546,68$ ha. Area of protected landscape Javorina is characterized by its geological structure, hydrogeological and hydrological phenomena and processes, soil types, mezzo and micro-climate, fauna, flora and vegetation. Based on the flora and vegetation as the basic elements and creators of the ecosystem, a number of important habitats have been selected: mountain turfs, crevices of limestone rocks, subalpine dwarf pine community, mountainous parts with preserved communities of mountain maple, frost forests, travertine and peat coal area. After evaluation and categorization the following categories have been determined: la -strict nature reservations, Ib - wilderness area, III - natural monument and IV habitat management area. Zone of I protection degree in the area of protected landscape consists of four separate units: Trijeska, Paloševina, Zlatna dolina javora and Dugo polje. In the zone of II protection degree there is Malo Dvorište and the habitat of the endemic species of Balkan Acer heldraichii subsp.visianii.
\end{abstract}

Key words: protected landscape, flora, vegetation, Jahorina.

\section{INTRODUCTION}

The Mountain Jahorina (hereinafter Jahorina) is located in the central part of Bosnia and Herzegovina and Republic of Srpska. It belongs to the continental Dinarides (Figure 1). The oldest data relating to the research of flora of Jahorina date back from the works by Fial (1893, 1895), Beck-Mannagetta (1927), Maly (1938, 1939), Bjelčić (1964-1965), Pavlović, Petronić (20042006). One of the first researchers of vegetation of Jahorina is Slavnić (1954). Forest vegetation was explored by Fukarek and Stefanović (1958), vegetation of premauntain meadows and pastures by Bjelčić (1966) and peatland ecosystems of the Mountain Ravna by Lakušić et al. (1981). Within preparations for the Winter Olympic Games in 1984, and for the needs of the Spatial and Regulatory Plan for special purposes mapping of vegetation in 10 Sarajevo municipalities was carried out where Jahorina was also included (Lakušić and Mišić 1982). Ruderal flora and vegetation was processed by Petronić (2000 and 2006). In the period from 2004 to 2006 the flora and vegetation of Jahorina was under thorough examination in the context of scientific and technical base for proclamation of Jahorina as protected area on the territory of Republic of Srpska. 


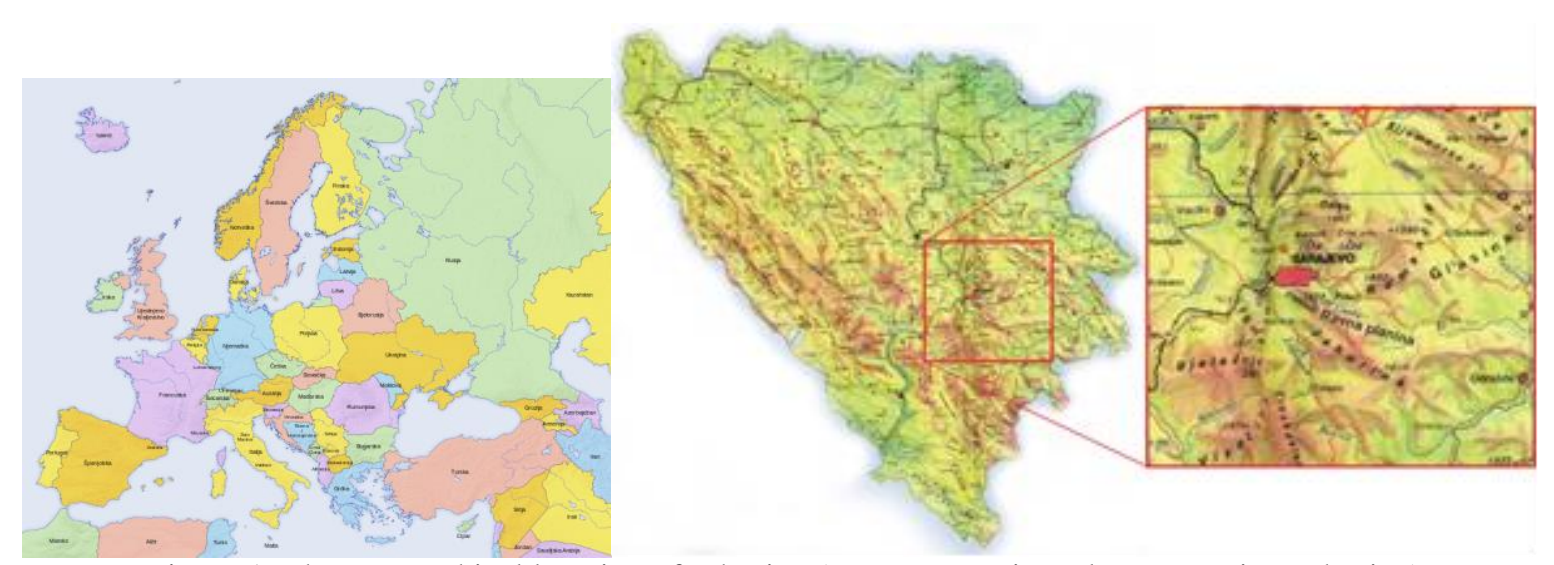

Figure 1. The geographical location of Jahorina (Europe-Bosnia and Herzegovina-Jahorina) https://commons.wikimedia.org/wiki/File:Europe_countries_map_2_hr.svg

\section{MATERIALS AND METHODS}

The study of flora and of vegetation was conducted in the period from 2004 to 2006. Transects method is used, and a large number of phytocoenological records in different ecosystems is made by the method Braun-Blanquet (1965). Floristic data were collected during the entire examination on the field at all locations in and outside the area of phytocoenological records. Identification of plant taxa was based on floristic literature (Beck, 1927; Josifović ed. 1970-1977; Javorka et Csapody, 1979). The nomenclature is in line with Flora Europaea (Tutin, et al. 1964-1980), and sintaxonomic review of vegetation is in line with Prodromusu plant communities of Bosnia and Hercegovina ( Lakušiću et al., 1978).

Republic Institute of the Protection of Cultural and Natural Heritage of Republic of Srpska synthesized existing literature data and results of research and performed scientific expert study as the basis for development and categorization of natural and cultural values of the zones and protection regimes. Valuation of area was carried out according to the Law on Nature Protection (Official Gazette of Republic of Srpska, 4/08) and IUCN categorization of protested natural areas.

\section{RESULTS AND DISCUSSION}

Area of protected landscape is $11,546,68$ ha, ranging from 900-1916 m (Figure 2). Based on the analysis of flora and vegetation of the massif of Jahorina evaluation and categorization have been made. Featured categories are: Ia - strict nature reservations, $\mathrm{Ib}$ - wilderness area, III - natural monument and IV - habitat management area.

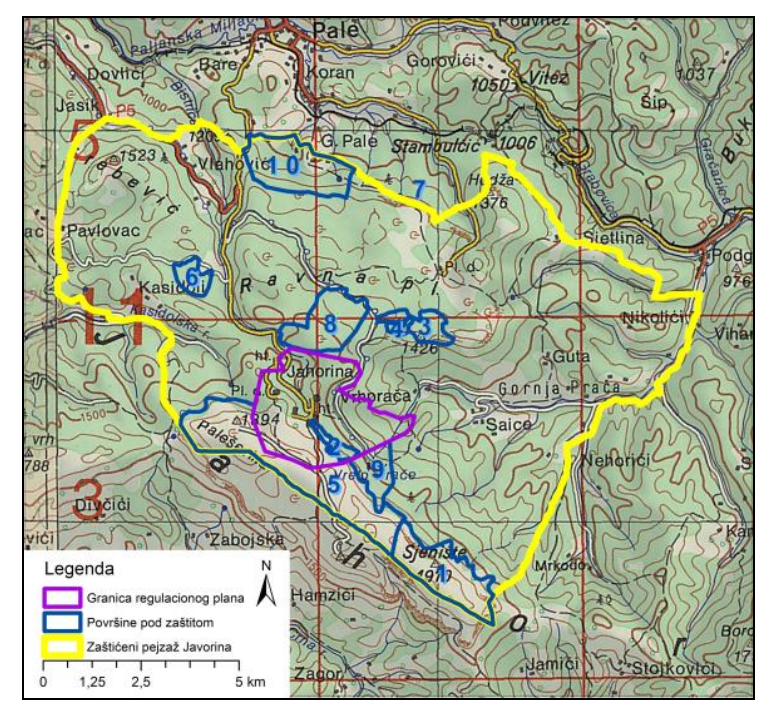

Figure 2. The boundaries of the planned Protected landscapes "Javorina" with the boundaries of special protection area

Within the boundaries of the protected areas regimes of protection I, II and III are proposed. Zone of I protection degree has an area of 976.68 ha, which is $8.34 \%$, the zone of II protection degree has an 
area of 976,68 hectares, or $5.86 \%$, while the zone of III protection degree is the largest one, with the area of 9,144.04 ha, or $79.19 \%$. Out of the total area of the protected landscapes, the Regulatory Plan of the Special areas Jahorina occupies 763.28 ha, or $6.61 \%$. Zone of I protection degree in the area of protected landscape consists of four separate units: Trijeska, Paloševina, Zlatna dolina javora and Dugo polje. In the zone of II protection degree there is Malo Dvorište and the habitat of the endemic species of Balkan Acer heldraichii subsp.visianii.

Flora of Jahorina consists of 1159 tax, both specific and infraspecific categories in section Lycopodiophyta, Equisetophyta, Pteridophyta, Pinophyta and Magnoliophyta, which makes up more than $20 \%$ of the total number of species represented in Bosnia and Herzegovina. Section Bryophytes includes about 180 tax (Grgic, 2009). The overall vegetation of Jahorina in phytocenosis terms differentiates 13 vegetation classes, 19 orders, 28 bonds, 57 associations and 10 sub-associations. A large number of classes, orders, and the bond of association is related to anthropogenic conditioned vegetation which is slightly represented in all zones of the protected area.

Category Ia - strict nature reservations „Trijeska“

Coordinates according to Gaus Kriger: East: 4837,364 N and 6551,386 E; West: $4839,112 \mathrm{~N}$ and 5648,803E; North: 4840,005 $\mathrm{N}$ and 6549,057 E; South: $4837,356 \mathrm{~N}$ and $6551,384 \mathrm{E}$

Size of protected area is 279.20 ha and includes part of Gola Jahorina. Strict nature reservation „Trijeska“ is covered with mountain grasslands that are the center of floristic, vegetation and ecosystem diversity. Around $7.78 \%$ of endemic species found refuge in them which is about $35.55 \%$ of the total number of endemic species of Bosnia and Herzegovina.

Vegetation of cracks limestone rocks on Jahorina is marginally represented on the site Trijeska. It belongs to endemic association Asplenietum fissi Horv. 1931. The community was poor in species. Important species that are represented are Saxifraga paniculata Miller, Dianthus petraeus Waldst. \& Kit. and Malcomia illyrica Hayek, Iris reichenbachii Heuffel. They can be found on Preliminary list of endangered species of Bosnia and Herzegovina. Smaller areas covered with dwarf pine, natural rarities and a dominant species of subalpine communities Pinetum mugo illyricum Fuk.1958 were present at Trijeska. The largest size of protected areas are covered with vegetation of mountain meadows on limestone class Elyno-Seslerietea Br.-Bl. 1948, order Seslerietalia tenuifoliae Horv 1930 and endemic alliance Seslerion tenuifoliae Ht 1930 Pawl. 1928. Association includes community of Dinaric endemic character LaevetoHelianthemetum alpestris $\mathrm{Ht}$ 1930. in which frequent species are Scabiosa silenifolia Waldst. \& Kit., Helianthemum canum (L.) Baumg., Carex kitaibeliana Degen, Hieracium villosum Jacq. etc.

Category Ia - strict nature reservations „Zlatna dolina javora”

Coordinates according to Gaus Kriger: East: 4841,786 N and 6547, $945 \mathrm{E}$; West: 4842,489 $\mathrm{N}$ and 6546,692 E; North: $4842,589 \mathrm{~N}$ and 6549,762 E; South: $4841,568 \mathrm{~N}$ and $6547,464 \mathrm{E}$

Subalpine forests of beech and maple Aceri-Fagetm subalpinum and subalpine forests of spruce Picetum subalpinum are developed on an area of 31.92 ha in which there are individual types of Acer heldraichii subsp. visianii. The main value of population of this region is 
young maple sub species Acer heldreichii subsp. visianii. /Nym..K.Maly./.

Below this level are mixed forests of beech, fir and spruce (Piceo-AbietiFagetum) with individual trees of maple.

North edge of this maple area is on Jahorina. The presence and distribution of maple is the main reason for the separation of the area in which appropriate protective measures will be implemented to protect and preserve the habitat of this Balkan endemic and relict species. In terms of maintenance, planning and development of natural resource it is allowed to monitor, perform scientific and technical research on the accepted and permitted projects from the competent institution. It is not allowed to carry out activities that would lead to changes in habitat conditions.

Category Ia - strict nature reservations „Dugo polje”

Coordinates according to Gaus Kriger:

East: $4845,135 \mathrm{~N}$ and 6549, $336 \mathrm{E}$; West: $4845,012 \mathrm{~N}$ and 6548,656 E; North: 4845,200 $\mathrm{N}$ and 6549,279 E; South: 4844,746 N and 6548,954 E

Dugo polje is located at $1380-1400 \mathrm{~m}$ above sea level. Geological base of the site make Werfenian sediments with soil type eugley and subtype eugley peat thickness 5-12 cm.

Smaller areas are vegetated with sfagnum peat. The special value of the field is given with the presence of carnivorous Drosera rotundifolia L. rare and relict species and the emergence of downy birch Betula pubescens represented with individual trees.

For the maintenance and improvement of the natural good, the surface 15,56 ha, it is necessary to monitor, perform scientific and technical research and visit in smaller groups in order to educate them.
Categorya $\mathrm{Ib}$ - wilderness area „Paloševina”

Coordinates according to Gaus Kriger:

East: 4840,067 N and 6549,133 E; West: 4842,466 $\mathrm{N}$ and 6543,407 E; North: 4843,165 N and 6544,134 E; South: $4839,112 \mathrm{~N}$ and $6548,803 \mathrm{E}$

Gola Jahorina represents the most deforested part of the mountain, the altitude of about 1660 meters to the highest peak of the mountain (1916 m).

Wilderness area Paloševina has area of 553.31 ha overgrown with Festucion pungentis Horv. 1930. The most widespread community of this combination are: Festucetum pungentis Horv. 1930, Brometo-Centauretum kotschyanae Horv. 1960, HypochoeretoFestucetum amethystinae Horvat 1960 and Anemono-Phleetum alpinae Bjelčić 1965. These communities build a large number of endemic and rare species from a preliminary Red List of Bosnia and Herzegovina, such as: Festuca bosniaca Kummer \& Koch, Dianthus giganteus D Urv. subsp. croaticus (Borbas) Tutin, Scorsonera purpurea subsp. rosea (Waldst. \& Kit.) Nyman, Pedicularis hoermanniana K. Maly, Polygala alpestris Reichenb. subsp. croatica Chodat) Hayek, Euphorbia montenegrina (Bald) K. May, Cerastium moesiacum Friv., Gentiana lutea L. subsp. symphyandra (Murb) Hayek, Hypochoeris illyrica, Achillea lingulata Waldst. \& Kit., Crepis dinarica Beck, Lilium bosniacum (G. Beck) G. Beck, Ranunculus croaticus Schott, Centaurea kotschyana Heuffel ex Koch, Hieracium aurantiacum L., Botrychium lunaria (L.) Swartz, Trollius europaeus L., Dactylorhiza sambucina (L.) Soo, Nigritela nigra (L.) Reichenb., a Pedicularis heterodonta Pančić and Viola elegantula Schott which is on the Red List of Europe (1991).

Endemic communities PlantagoBarbaretum illyricae have been 
developed on the trampled habitats, while edificator species Plantago reniformis and Barbarea bosniaca are on the Red List of Europe.

Vegetation of mountain meadows on acid soils occupies less space. Endemic communities Crepido conyzifoliae-Lilietum bosniacae Bjelčić 1966 is present on the surfaces within the mountain meadows on limestone. Edificator species Crepis conyzifolia (Gouan) A. Kerner and Lilium bosniacum (G. Beck) G. Beck are endemic, rare and endangered species.

Category III - natural monument „Malo Dvorište"

Coordinates according to Gaus Kriger: East:4846,374 N and 6544,212 E; West: $4846,503 \mathrm{~N}$ and $6543,225 \mathrm{E}$; North: 4846,750 $\mathrm{N}$ and 6543,775 E; South: $4845,768 \mathrm{~N}$ and $6543,954 \mathrm{E}$

Natural monument „Malo Dvorište“ occupies area of 58.14 ha. The main value of this area is the presence of the community Picetum montanum inversum frosty forests of spruce caused by specific ecological conditions, primarily temperature inversion in relation to the surrounding area. This community is dominated by spruce, and there are individual trees Pinus sylvestris and Abies alba. Blueberry bushes form a low floor. Of the other plants the following are significantly represented: Deschampsia flexuosa (L.) Trin, Veronica officinalis L., Gentiana asclepiadea L., Melampyrum hoermannianum K. Maly, and endemic species Viola elegantula SchottMoss makes a well-developed floor. The presence of lichens on trees is significant. Forests of beech, fir and spruce continue on this forest. The lowest parts of the frost areas are covered with meadow communities.
Category IV - IV - habitat management area „Veliki javor”

Coordinates according to Gaus Kriger:

East: $4845,446 \mathrm{~N}$ and 6548,214 E; West: $4844,845 \mathrm{~N}$ and 6545,912 E; North: $4845,976 \mathrm{~N}$ and $6547,170 \mathrm{E}$; South: $4844,348 \mathrm{~N}$ and $6546,854 \mathrm{E}$

Veliki javor occupies area of 217.93 ha. It is covered by forests of spruce, fir and beech (Piceto-Abieti-Fagetum). In these forests there is a significant presence of maple trees in all floors. Floor of herbaceous plants is rich in seedlings and offspring of maple. Numerous offspring need conditions for survival to be ensured with appropriate active measures. In addition to the offspring, there are individual old trees of impressive dimensions. Protection of this type is important for the preservation of biodiversity and the survival of the species in extreme northern boundary of its distribution. It is necessary to monitor the development of mountain maple population, increase the share of renewal of maple seeds or plants and, if necessary, apply biological control against insects and plant causes of disease.

\section{Water protection forest Vrela Prače}

Coordinates according to Gaus Kriger:

East: $4841,013 \mathrm{~N}$ and $6548,839 \mathrm{E}$; West: $4841,573 \mathrm{~N}$ and 6547,736 E; North: 4842,063 N and 6548,744 E; South: $4840,244 \mathrm{~N}$ and $6548,481 \mathrm{E}$

The area has a surface of 102.94 ha. This area is managed for sustainable use of natural ecosystems. In the scope of water protection zones best preserved beech and fir with spruce grow (Piceto-AbietiFagetum). In this scope mesophilic mountain meadows alliance Pancicion with two endemic associations were observed Pancicio-Lilietum bosniacae Bjelčić and Lakušić 1969 and Alchemillo- 
Crepidetum bosniacae Bjelčić 1967. In these communities, number and cover effect of rare and endemic species Pimpinella serbica (Vis.) Bentham, Lilium bosniacum (G. Beck) G. Beck, Crepis aurea (L.) Cass., Knautia dinarica (Murb.) Borbas, Alchemilla maly, Dactylorhiza cordigera (Fries) subsp. bosniaca (G.Beck) Soo are dominant, while the following species are less numerous Polygala alpestris (Reichenb. subsp. croatica (Chodat) Hayek.

A significant floristic and vegetation diversity of Jahorina, the presence of a significant number of endemic, rare and endangered species and communities, imposes the necessity of long-term preservation and improvement. This includes adequate legal protection, management expertise, training and involvement of local communities in the protection system.

\section{CONCLUSION}

The total area of protected landscape Javorina is 11 . 546,68 ha. Within this area there are extremely important landscapes, ecosystems, hydrological facilities, natural rarities and historical and cultural values that are submitted to various forms of protection, harmonized with European standards.

Zone of I protection degree in the area of protected landscape consists of four separate units: Trijeska, Paloševina, Zlatna dolina javora and Dugo polje In the zone of II protection degree there is Malo Dvorište and the habitat of the endemic species of Balkan Acer heldraichii subsp.visianii. Within the protected landscape Javorina, based on the analysis of flora and vegetation of the massif of Jahorina evaluation and categorization have been made. Featured categories are: Ia - strict nature reservations, Ib - wilderness area, III natural monument and IV - habitat management area.
Based on the analysis of flora and vegetation of the massif of Jahorina, was allocated a number of important habitats. These are mountain grasslands Gola Jahorina, cracks limestone rocks, subalpine pine community (Sjenište, Trijeska), highlands with preserved forest communities (Mali javor, Veliki javor, Vrelo Prače), frost forests (Mala Dvorišta), peat coal area (Paljanska Miljacka) and travertine (Dugo polje).

The concept of the protection of the protected landscape Javorina is based on the protection, development, planning and management of protected landscape, which includes the preservation and improvement of the overall natural values and resources.

\section{REFERENCES}

Beck, G., 1927. Flora of Bosnia and Herzegovina and the Sanjak of Novi Pazar part III book XV. Belgrade Sarajevo. Serbian Royal Academy.

Beck, G., 1950. Flora of Bosnia and Herzegovina IV Sympetale, part: 1 . Labiatae. Sarajevo. Brightness.

Bjelčić, Ž. 1967. Flora of Bosnia and Herzegovina, IV Sympetale, part 1: Scrophulariaceae. Sarajevo. National Museum Bi H.

Bjelčić, Ž. 1974. Flora of Bosnia and Herzegovina, Sympetalae, IV Sympetale, part 3: Labiatae. Sarajevo. National Museum Bi H.

Bjelčić, Ž. 1965. Flora of Jahorina mountain. Sarajevo. National Museum $\mathrm{Bi} \mathrm{H}$.

Bjelčić, Ž. 1966. Vegetation of the submountain zone of Jahorina. Sarajevo. National Museum Bi H.

Braun-Blanquet. J. 1964.Phytosociology. Wien - New York. Springer Verlag.

Fukarek, P. and Stefanović, V. 1958. Research and mapping of forest vegetation of Jahorina, Igman, Ljubinje, Velez and the area around the Drina. National forest, 10-12. 
Javorka, S. and Cspody, V. 1979. Iconography of the flora of southeastern Central Europe. Budapest. Akademia Kiado.

Josifović, M. 1970-1972. Flora of Serbia I-X. Belgrade. Serbian Academy of Sciences and Arts.

Lakušić, R. 1964. Mountain maple Vol. XVII. Sarajevo. Yearbook of Biology, University of Sarajevo.

Lakušić, R. 1990. Mountain plants. Sarajevo, Belgrade. Department of textbooks and teaching aids.

Maly, K. 1938-1939. The Ravna mountain in Pale I-II. Sarajevo National Museum of Bosnia and Herzegovina.

Mišić, Lj. and Lakušić, R. 1990. Meadow plants. Sarajevo, Belgrade. Department of textbooks and teaching aids.

Petronić, S. and Pavlović, D. 2003, Cirsietum candelabri ruderal community of Pale area. The symposium with international participation - Improving agricultural production in the territory of Kosovo and Metohija. Lešak.

Petronić, S., Pavlović, D. and Milić, V. 2010. Ruderal flora of Pale. Archive for the Engineering Sciences, 2:86-90.

Slavnić, Ž. 1954. About the vegetation of the mountain folds in Bosnia, Annual Institute of Biology, University of Sarajevo, 1-2: 169-180.

Stefanović, V. 1983. Vegetation of the Olympic Mountains. Biological magazine, 5-6: 72-76. 7-8: 99-104.

Šilić, Č. 1973. Atlas of trees and bushes. Sarajevo. The Institute for Textbooks.

Šilić, Č. 1977. Forest herbaceous plants. Sarajevo, Zagreb, Beograd. Brightness, Schoolbook, Vuk Kardžić.

Šilić, Č. 1990. Endemic plants. Beograd Department of textbooks and teaching aids.

Šilić. Č. 1996. List of plant species (Pterydophyta and Spermatophyta) for the Red Book of Bosnia and
Herzegovina, National Museum of Bosnia and Herzegovina, 31: 323-367. Tutin, T.G. 1964-1980. Flora Europaea 15. London. Cambridge University Press. 